\title{
GENDER DIVERSITY AND EDUCATIONAL ATTAINMENT IN NON-LISTED PRIVATE FIRMS: EVIDENCE FROM SLOVAKIA*
}

\author{
Pavol OCHOTNICKÝ - Nick WILSON - Marek KÁČER - Martin ALEXY
}

(Received: 14 June 2017; revision received: 20 November 2017; accepted: 16 March 2018)

\begin{abstract}
The paper tests the impact of gender diversity and educational attainment of owners and company directors on the performance of private firms in the Slovak economy. The paper demonstrates that in retail trade the gender diversity both in owners and company directors within a company leads to higher total factor productivity and partially lower propensity to fail. However, in other industries the companies with higher proportion of females in the ownership structure or among company directors tend to be less efficient and grow less. Although there is evidence that higher proportion of females self-select into lower risk sectors and occupations, our main results hold after controlling for it. In terms of educational attainment, the companies with higher proportions of owners or company directors with university education are more productive and grow more in terms of turnover, but there is no evidence that default of companies is related to educational attainment. We suggest that education is unique and superior resource and it generally benefits the companies by having higher proportion of educated owners and/or directors.
\end{abstract}

Keywords: corporate governance, gender diversity, educational attainment

JEL classification indices: G32, G33

* The paper is an outcome of two research projects: "Determinants of firms' default in developed and converging economies" supported by VUB Foundation and "Competitiveness, economic growth and firm survival" (APVV-15-0322) supported by Slovak Research and Development Agency. The research is co-financed by the European Union.

Pavol Ochotnický, Professor and Head at the Department of Finance, Faculty of National Economy, University of Economics in Bratislava. E-mail: pavol.ochotnicky@euba.sk

Nick Wilson, Professor and Director at the Credit Management Research Center of Leeds University Business School. E-mail: n.wilson@lubs.leeds.ac.uk

Marek Káčer, Assistant Professor at the Department of Finance, Faculty of National Economy, University of Economics in Bratislava and Post-doctoral researcher at the Leeds University Business School. E-mail: marek.kacer@gmail.com

Martin Alexy, corresponding author. Assistant Professor at the Department of Finance, Faculty of National Economy, University of Economics in Bratislava. E-mail: martin.alexy@euba.sk 


\section{INTRODUCTION AND MOTIVATION}

The issue of board level diversity and company level performance has attracted much interest conceptually, empirically and also in relation to policy intervention. The debate about diversity and the possible imposition of quotas in the form of increasing the number of women in boards of directors, and the debate about increasing education attainment of board members in the European Union (EU) are the motivations for undertaking this study. In this paper using econometric methods we examine the relationships between dimensions of firm performance and variations in gender diversity and also education attainment. Policy interventions in relation to board diversity are based on the premise that directors' heterogeneity in terms of gender and education (general or specific human capital) is beneficial for firm performance.

Many academic and empirical studies have sought evidence on the governance-performance relationship predominantly from large and listed companies in the developed economies. In comparison to the developed economies there is less evidence of the impact of board composition in the emerging and transition economies and from the broader cross-section of enterprise types. Indeed, Kang et al. (2007) argue that the generalisability of the previous findings from, predominantly, large US listed companies e.g. Erhardt et al. (2003) "may not extend across national boundaries due to different regulatory and economic environments, cultural differences, the size of capital markets and the effectiveness of governance mechanisms" (Kang et al. 2007:194). The Slovak Republic has its own specificities: it is an economy that has experienced post-communist transition, convergence to the EU and weathered the financial tsunami of 2008.

Trying to answer the question of how gender diversity and educational attainment relate to various measures of corporate performance - productivity, growth and survival - our paper focuses exclusively on privately held limited liability companies (LLC). The main reason of excluding the listed companies is that most of them are subsidiaries of big international corporations ${ }^{1}$ where firm strategy and key decisions are mainly determined by the boards of the parent companies, and data on gender structure and education level are not reported in the official registers. Our analysis includes data from 2012-2014, which covers a more stable post transition and recession period and is characterised by more steady economic growth, stable industry structure and high spill-over effects from foreign direct investment (driven by the automobile industry). Although there are many studies on firm level performance post transition-enlargement (Wilson et al. 2016), we

1 Mainly in the automobile industry and in bank and insurance sectors. 
are not aware of any that incorporates detail of the stakeholders' characteristics (owners and directors) and their diversity.

As it has been recognised that the impact of gender diversity is ambiguous (Carter et al. 2010), a multidimensional approach in a way reconciles the contradictions by providing a broader picture and elucidating how it affects various dimensions of company performance. The same holds for educational attainment. In examining performance, unlike previous studies, we choose several dimensions including efficiency, growth and survival (exit via bankruptcy).

The paper is structured as follows. In Section 2, we provide review of the literature on the effects of board diversity and educational attainment on corporate performance. Section 3 gives a context with a discussion of the development of the Slovakian corporate sector, gender studies and impact of education on the corporate sector. Section 4 outlines our methodology in relation to the dimensions of firm level performance and it also includes our modelling strategy. The fifth section explains our dataset and the composition of the variables. The sixth Section provides estimation results and sensitivity analysis. In Section 7 we discuss the results while the last Section gives conclusions.

\section{LITERATURE REVIEW}

So far, only a handful of studies have attempted to determine the role of directors on the performance of the corporate spectrum including small and medium-sized enterprises (SMEs) and family businesses (Wilson et al. 2013). In unravelling causal relationships it is acknowledged in the previous studies of larger and established enterprises that directors' selection, board characteristics and company performance are likely to be endogenous (Anderson et al. 2011). This, of course, confounds the problem of measuring the impacts of director heterogeneity and board diversity on the performance. In recently incorporated companies, the ownership, board and top management overlap to a great extent (Brunninge et al. 2007). However, in investigating gender effects we are concerned to test whether the gender composition of owners/directors is industry specific. For instance, female presence is higher in lower risk, more stable sectors or females are more likely to invest in 'life-style' businesses and avoid higher risk ventures.

Effective boards are influenced by their configuration of expertise, the ownership type, structure and sector of the firm and the life-cycle phase of the firm. The dimensions of directors' expertise include: gender and ethnic diversity; age and sector experience; networks and contacts; previous business and board experience and multiple board membership; prior successes and failures; and board stability versus replacement. Diverse boards are more likely to incorporate the 
range of expertise and networks highlighted above. We focus on two main dimensions that can be measured within our dataset: gender diversity and educational attainment that capture human and social capital of the firm owners and executive directors (in the rest of the paper for the sake of brevity we use the term director). We study firm performance from three perspectives and therefore our research question: "What is the impact of gender diversity and educational attainment on firm performance?" is related to productivity (or efficiency), growth and survival of a company.

\subsection{Gender diversity}

It is widely believed that a company with a balance of gender on the board will have access to a wider pool of human capital than male-only boards with more potential to create competitive advantages (Barney 2001). Women provide information and insights unique to female experiences and their complementary networks (Brammer et al. 2007). Female directors, because of their participation in certain consumer markets may have expertise in and unique knowledge of product markets that is helpful in product positioning and in gaining a wider customer base. Gender diverse boards are likely to be more cognisant with the range of customer needs.

Moreover, female directors may have important knowledge of specific labour markets, skills and access to relevant task-related human capital. Jehn et al. (1999) find that groups with more diversity generate more innovative and critical thinking in problem solving. Huse et al. (2010) suggest that a higher ratio of women directors may contribute to reducing board level conflicts, and creating more time for strategic tasks and developmental activities. Empirical studies on gender diversity and performance outcomes have not produced clear-cut results. Carter et al. (2010), for instance, examine the impact of women and ethnic directors on the boards of large US companies. After extensively reviewing the literature from a range of theoretical lenses, i.e. resource dependence theory, human capital theory, agency theory and social psychology, they conclude that "the effect of the gender and ethnic diversity of the board may be different under different circumstances at different times" (Carter et al. 2010: 396). Most empirical studies focus on large companies and, clearly, smaller companies are likely to have different and weaker governance practices. Thus, gender diversity on the board of smaller companies may help strengthening board effectiveness and performance outcomes. 


\subsection{Educational attainment}

In the literature, educational attainment has been used as a proxy for human capital. However, educational attainment is not only a proxy for knowledge, skills and intelligence but also for social connections which may be particularly important in economies where traditional business networks have not been fully developed. These social connections can be with other business owners and/or connections with high level professionals in business services (accounting, legal services, finance), professional bodies, the banking sector and government. This may be particularly the case in Slovakia, where firm stakeholders that have achieved a high level of educational attainment can add considerable value to firms that lack these networks and skills and at the same time complement the directors and stakeholders that have acquired more task-related human capital based on their experience rather than formal education. This is not to say that the fast-growing and high-performing firms in the post transition economies are all managed by people who are highly-educated, but education brings both specific and general skills (human capital) that are relevant to successful businesses.

There is a broad stream of empirical supports for a positive relationship between the performance of entrepreneurs and education. The meta-analysis of van Praag et al. (2009) includes many studies with the focus on the relationship between education and entrepreneurship. One of the main conclusions is that the relationship between schooling and entrepreneurship performance is positive, and significant in two thirds of empirical studies, irrespective of the performance features, such as survival, profit, income or firm growth.

\section{CONTEXT: SLOVAKIA}

\subsection{Slovakian corporate sector}

In comparison to the developed countries (e.g. older member states of the EU), where the private sector has grown over many years, the post communism history-length of the private LLC sector in the transition economies can be measured in decades. Entrepreneurial ventures in Slovakia have a relatively short history.

The options for structuring business entities in Slovakia are, like elsewhere, either commercial companies or sole entrepreneurs. The latter is a type of business owned and run by an individual person. The legal forms of commercial companies are joint stock company, limited liability company, limited partnership and general partnership. There is a substantial growth in the number of commercial 
companies in Slovakia since the economy has changed into free market economy. In 1993 a total of 20,850 commercial companies had been registered, while in 2014 the number grew to 184,258 . The proportion of LLC (of all commercial companies) increased from $87.0 \%$ in 1993 to $96.1 \%$ in 2014 . The number of LLC grew more than nine times between 1993 and 2014, while the number of sole entrepreneurs has increased only by $28 \%$ during the same period. ${ }^{2}$

Our focus is on LLCs because of their predominance in the economy, our unique data, and the gap in the literature. The growth of LLCs has been on an upward trajectory since 2004, and thus much of the growth has taken place in the last 10 years. These companies can therefore be considered as relatively new corporations. Indeed, studies of company survival find that new corporations are at the highest risk of failure up to 8-10 years threshold before being regarded as established (e.g. Wilson - Altanlar 2014). Our sample therefore presents an interesting test ground for examining the diversity-performance relationships.

\subsection{Gender regime in Slovakia}

The Slovakian society was traditionally conservative and place of woman was seen in the family circle with the traditional role of wife and mother. The right to vote was granted relatively early, in 1919, considering that in some European countries it was as late as in 1971 (Switzerland) or 1984 (Lichtenstein). After the change of political regime in 1989 and especially in relation to EU entry Slovakia had to adopt agenda and legislation in favour of gender equality. However, Slovakia still belongs to the list of countries with the lowest representation of females in top politics (only 16\% of females in parliament) and with persistent gender pay gap.

Discussion on gender diversity in a corporate sector is mostly driven by gender equality in areas of wages and pay gap, segregation in a labour market and gender gap in employment. Bútorová et al. (2008) in their comprehensive social study suggest that even though women are seen as a part of a company, they have fewer opportunities for self-realization in comparison to men. Institutions, which should strengthen balanced gender representation, did not seem to implement gender equalization themselves. They found that women's representation among legislators, senior officials and managers remained nearly same between 2000 and 2007 and was less than one third in 2007. Fidrmuc - Senaj (2014) analysed the household expenditure survey data for Slovakia during the period of 2004 to 2009 and found that the households with a female principal earner had the

2 Data from the Statistical Office of the Slovak Republic. 
incomes lower by 4.8 percentage points on average. There has been very little research done in Slovakia related to gender diversity and corporate governance or firm performance.

\subsection{Education and corporate sector}

Bútorová et al. (2008) found that there is a strong relationship between the employment rate and education status. The lowest employment rate has been traditionally linked to a workforce with elementary education. University education has been associated with higher wages; Eriksson (2005) confirmed that CEOs with university education earn more in both Slovakia and Czech Republic. Bartoš et al. (2015) found that there are significant differences in the attitudes of entrepreneurs with and without university degrees, and also in their motives for starting businesses: university graduates more often start their own business. However, the impact of education on companies' profitability or the ability to manage financial risks was not confirmed. Their research was conducted on a sample of 449 owners of companies in Czech Republic and Slovakia. Findings of Van der Zwan et al. (2016) indicate that entrepreneurship education positively relates to engagement in the opportunity driven entrepreneurial activities and also reduces the odds of failure for the opportunity motivated entrepreneurs. Slovakia is included in the survey data for 33 European countries used by the authors.

The studies cited above provide evidence that it is beneficial for entrepreneurs to have a university degree. In Slovakia, the proportion of people with tertiary (university) education is constantly increasing and this trend is present Europewide. The EU goal is that by 2020 at least $40 \%$ of the population between the age of 30 to 34 years have completed tertiary education. Among four countries in Visegrad, Slovakia (similar to Czech Republic) used to have the lowest figures, however, as of 2016, its position (31.5\%) is similar to Hungary (33.0\%) and Czech Republic (32.8\%), still substantially below its 2020 goal of $40 \%$.

\section{PERFORMANCE MEASURES AND MODELLING STRATEGY}

\subsection{Efficiency/Production function approach}

To examine the differences in productive efficiency we specify a production function model using the firm level data. In this model, we relate total output (real value added) to labour and capital inputs, and then isolate productivity differentials for company types. The production function specification is Cobb-Douglas, 
which is frequently used in academic empirical studies of ownership-governanceperformance linkages. In equation (1) the dependent variable is output in terms of real value added (deflated using GDP deflator). The main explanatory variables used for the production function models are number of employees (labour) and real fixed assets (capital). The equation for estimation is as follows:

$$
\log \left(Y_{i, t}\right)=\beta_{0}+\beta_{1} \log \left(L_{i, t}\right)+\beta_{2} \log \left(K_{i, t}\right)+\beta_{3} C_{i, t}+\beta_{4} E_{i, t}+u_{i, t}
$$

where $Y$ stands for real value added output, $L$ for number of employees, $K$ for real fixed assets, $C$ for the vector of other control explanatory variables (age in years, industry effects, regional effects, time effects and size effects) and $E$ for owners' and directors' composition variables. The additional explanatory variables essentially explain firm level differences in total factor productivity (TFP) that are not attributed to the main explanatory variables. The residual from the basic production function isolates the efficiency differences in firms attributed to technological progress, knowledge and know-how, management practices and other factors that increase efficiency. However, the preliminary results showed that it does not matter whether we use two-step approach, where either we first estimate the model using just the main explanatory variables (labour and capital), isolate the residual (TFP) and in the second stage we estimate the equation of interest using remaining explanatory variables, or estimate all the parameters in one step. Therefore, we report the main results that are obtained using the simpler one-step approach. The variables used for the model are described in Table 1.

Table 1. Definition of variables

\begin{tabular}{|c|c|}
\hline Variable & Definition \\
\hline \multicolumn{2}{|c|}{ Productivity model - control explanatory variables } \\
\hline Real value added $(\log )$ & $\begin{array}{l}\text { Natural logarithm of value added deflated to } 2012 \text { prices } \\
\text { (GDP deflator) - dependent variable }\end{array}$ \\
\hline $\begin{array}{l}\text { Labour } \\
\text { (number of employees, log) }\end{array}$ & Natural logarithm of number of employees \\
\hline Capital (real fixed assets, log) & $\begin{array}{l}\text { Natural logarithm of fixed assets deflated to } 2012 \text { prices } \\
\text { (GDP deflator) }\end{array}$ \\
\hline \multicolumn{2}{|c|}{ Growth models - control explanatory variables } \\
\hline Real turnover growth & $\begin{array}{l}\text { Compound annual growth rate of turnover deflated to } 2012 \\
\text { prices (GDP deflator) - dependent variable }\end{array}$ \\
\hline Real total assets growth & $\begin{array}{l}\text { Compound annual growth rate of total assets deflated to } 2012 \\
\text { prices (GDP deflator) - dependent variable }\end{array}$ \\
\hline Size (Turnover, log) & Natural logarithm of turnover \\
\hline Size (Total assets, log) & Natural logarithm of total assets \\
\hline Total debt/ Total assets (w) & Total debt divided by total assets, winsorized at $5 \%$ and $95 \%$ \\
\hline
\end{tabular}


Table 1. continued

\begin{tabular}{|c|c|}
\hline Variable & Definition \\
\hline HHI (turnover) & $\begin{array}{l}\text { Hirschman-Herfindahl index calculated for each year and } \\
\text { industry sector ( } 21 \text { sectors based on two-digit NACE codes, see } \\
\text { Table 12) }\end{array}$ \\
\hline Diversification indicator & $\begin{array}{l}\text { Indicator of activities in more industrial sectors ( } 21 \text { sectors } \\
\text { based on two-digit NACE codes, see Table } 12 \text { ), equal to one if } \\
\text { the company is active in more than one sector, zero otherwise }\end{array}$ \\
\hline \multicolumn{2}{|c|}{ Default model - control explanatory variables } \\
\hline Default indicator & $\begin{array}{l}\text { Indicator of default, equal to one if the company defaulted in the } \\
\text { year following the submission of financial statement }\end{array}$ \\
\hline Cash/ Total Assets (w) & $\begin{array}{l}\text { Cash and bank accounts divided by total assets, winsorized at } \\
5 \% \text { and } 95 \%\end{array}$ \\
\hline $\begin{array}{l}\text { Trade Creditors/ Total } \\
\text { Liabilities (w) }\end{array}$ & $\begin{array}{l}\text { Accounts payable divided by total liabilities, winsorized at } 5 \% \\
\text { and } 95 \%\end{array}$ \\
\hline $\begin{array}{l}\text { Pre-tax profit/ Total Assets } \\
\text { (w) }\end{array}$ & Pre-tax profit divided by total assets, winsorized at $5 \%$ and $95 \%$ \\
\hline Net Worth/ Total Assets (w) & $\begin{array}{l}\text { Net worth (equity) divided by total assets, winsorized at } 5 \% \text { and } \\
95 \%\end{array}$ \\
\hline Size (Total assets, log) & Natural logarithm of total assets \\
\hline
\end{tabular}

\section{Control explanatory variables included in all models}

Age (years)

Industry fixed effects

Regional fixed effects

Time fixed effects

Size indicators
Age of the company - difference between the year of financial statements and the year when the company was founded Indicators of industry sectors (21 sectors based on two-digit NACE codes, see Table 12), equal to one if the company is active in given sector, zero otherwise

Indicators of regions (8 geographic regions in Slovakia), equal to one if the registered address of the company is in given region, zero otherwise

Indicators of years (3 years - 2012, 2013,2014), equal to one if the company-year observation is from given year, zero otherwise

Indicators of size (micro, small, medium and large, according to SME definition), equal to one if the company is from given size group, zero otherwise

\begin{tabular}{|c|c|}
\hline \multicolumn{2}{|c|}{ Explanatory variables of interest } \\
\hline Female - owners & $\begin{array}{l}\text { Proportion of females among company owners, equal to number } \\
\text { of female company owners divided by number of all owners }\end{array}$ \\
\hline $\begin{array}{l}\text { Female - owners } \\
(0.34-0.66)\end{array}$ & $\begin{array}{l}\text { Equal to one if proportion of females among company owners is } \\
\text { between } 0.34 \text { and } 0.66 \text {, zero otherwise }\end{array}$ \\
\hline Female - owners (over 0.66) & $\begin{array}{l}\text { Equal to one if proportion of females among company owners is } \\
\text { higher than } 0.66 \text {, zero otherwise }\end{array}$ \\
\hline Female - directors & $\begin{array}{l}\text { Proportion of females among directors, equal to number of } \\
\text { female directors divided by number of all directors }\end{array}$ \\
\hline $\begin{array}{l}\text { Female - directors } \\
(0.34-0.66)\end{array}$ & $\begin{array}{l}\text { Equal to one if proportion of females among directors is } \\
\text { between } 0.34 \text { and } 0.66 \text {, zero otherwise }\end{array}$ \\
\hline
\end{tabular}


Table 1. continued

\begin{tabular}{ll}
\hline Variable & \multicolumn{1}{c}{ Definition } \\
\hline Female - directors (over 0.66) & $\begin{array}{l}\text { Equal to one if proportion of females among directors is higher } \\
\text { than 0.66, zero otherwise } \\
\text { Proportion of company owners with university education, } \\
\text { equal to number of company owners with university education } \\
\text { divided by number of all owners } \\
\text { Equal to one if proportion of company owners with university } \\
\text { education is between 0.34 and 0.66, zero otherwise }\end{array}$ \\
$\begin{array}{l}\text { Education - owners ( } 0.34- \\
0.66)\end{array}$ & $\begin{array}{l}\text { Equal to one if proportion of company owners with university } \\
\text { education is higher than 0.66, zero otherwise }\end{array}$ \\
Education - owners (over & $\begin{array}{l}\text { Proportion of directors with university education, equal to num- } \\
\text { ber of directors with university education divided by number of } \\
\text { all directors }\end{array}$ \\
Education - directors & $\begin{array}{l}\text { Equal to one if proportion of directors with university education } \\
\text { is between } 0.34 \text { and } 0.66, \text { zero otherwise }\end{array}$ \\
Education - directors $(0.34$ & $\begin{array}{l}\text { Equal to one if proportion of directors with university education } \\
\text { is higher than 0.66, zero otherwise }\end{array}$ \\
$-0.66)$ &
\end{tabular}

\subsection{Growth}

We studied companies' growth along two dimensions - turnover and total assets. The basic model is presented in equation (2). The dependent variable is compound annual growth rate from 2012 to 2014. The growth is calculated using deflated variables (GDP deflator was used) in order to exclude the impact of price level. This analysis is cross-sectional - using the information from 2012 we aim to explain the average annual growth rate that occurred between 2012 and 2014. The control explanatory variables for the growth models are size (measured in total assets), total debt to total assets, age, competition (measured by HirschHerfindahl index of turnover within the industry sector), and indicator of diversification. Thus, the estimation equations are as follows:

$$
\text { Growth }_{i}=\beta_{0}+\beta_{1} C_{i}+\beta_{2} E_{i}+u_{i}
$$

where Growth stands either for turnover or total assets growth, $C$ represents the vector of control explanatory variables (besides those mentioned above variables we also include the variables common to all models - age, industry, regional and size indicators; we do not include time indicators here since these models are cross-sectional) and $E$ stands for the main explanatory variables of interest, i.e. owners' and directors' composition variables. The variables used for the model are described in Table 1. 


\subsection{Survival/Bankruptcy}

Finally, we estimate the models determining survival/failure. In this analysis, we develop the logit model of default prediction. The literature aimed at default prediction using the financial ratios is rich and the notable milestones are Beaver (1966), Altman (1968), Ohlson (1980), Zmijewski (1984) and Shumway (2001).

The dependent variable is binary and represents the event of default (Equation 3 ). To construct the variable, we checked the legal documents attached to the companies marked as defaulted in our database. The use of financial variables as predictors for default has a long history in developed economies. Usually the ratios used for default prediction are the measures of liquidity, solvency and profitability. The non-financial information often offers additional information to the financial ratios and that is why they are used for default modelling, as well (Altman et al. 2010). In our study the initial set was similar to Wilson et al. (2016), however, the final set of control variables is slightly different, possibly due to the differences of the sample in terms of the number and size of the companies and the sample period. Hence, the set of financial control variables includes the following financial ratios: Cash to Total assets, Trade creditors to Total liabilities, Pre-tax profit to Total assets and Net worth to Total assets. The set of control variables related to the non-financial information consists of age and indicators of industry sector, region, time and size. The model specification used for the default prediction is as follows:

$$
P\left(d_{i, t+1}=1 \mid \Omega_{t}\right)=1 /\left\{1+\exp \left[-\left(\beta_{0}+\beta_{1} F_{i, t}+\beta_{2} N_{i, t}+\beta_{3} E_{i, t}+u_{i, t}\right)\right]\right\}
$$

where $F$ stands for financial variables, $N$ for non-financial variables and $E$ means explanatory variables of interest, i.e. owners' and directors' composition variables. The variables used for the model are described in Table 1. Since accounting ratios are often subject to outlying and extreme values that can potentially bias our multivariate estimates, particularly for private companies, we apply a consistent strategy for dealing with the outliers (winsorization).

\section{DATASET AND CONSTRUCTION OF OWNERS' AND DIRECTORS' COMPOSITION VARIABLES}

\subsection{Dataset description}

The sample used in this study originates from one of the largest corporate credit reference databases of the Slovakian companies (database Albertina from 
Bisnode). Firstly, data of all LLCs were extracted, including financial statements covering financial years of 2012, 2013 and 2014, company characteristics and information about owners and company directors (as of March 2013). The process of elimination was as follows: Firstly, a company was excluded if gender of at least one owner or company director was unknown. Secondly, as is explained below, because of the data limitation related to the indicators of university education, we had to restrict the sample only to companies with inland ownership. Thirdly, we removed companies with no owners or no company directors. The fourth and final criterion for keeping a company-year observation in the estimation sample was that there are no missing values for any variables needed to estimate at least one model (i.e. either productivity, growth or default model). In case of multiple statements for a given company and in a year, only the last updated version was used. The final estimation sample pool for this study contains 245,220 company-year observations on 100,242 Slovakian LLC and therefore represents a substantial proportion of the Slovakian corporate population ${ }^{3}$.

\subsection{Construction of owners' and directors' composition variables related to gender and education}

The main purpose of this study is to explore how gender composition and educational attainment are related to enterprise performance. In general, the important explanatory variables used in this study are constructed as proportions of persons with characteristic of interest. Since there are two types of specific positions of responsibility related to LLC - owners and directors, our explanatory variables of interest relate to gender and educational attainment of both owners and directors.

Firstly, we construct four variables: 1) proportion of females among company owners, 2) proportion of females among company directors, 3) proportion of owners with university education and 4) proportion of company directors with university education.

3 Majority of LLCs in our estimation sample qualifies as SME according to the main criteria set forth by European Commission (criteria based on number of employees, total assets and turnover). Out of all company-year observations, 200,803 qualifies as micro company, 18,840 as small company, 2,439 as medium-sized company and 165 as large company. We could not identify 23,274 company-year observations because of missing values for number of employees, but except 55 all seem to be micro enterprises based on other two criteria (total assets and turnover). However, in the paper we use all LLCs since we did not see any compelling reason to focus exclusively on SMEs. 
However, these variables are not used directly in the estimations. We expect non-linear relationships and at the same time are interested in the impact of the specific values of proportions. That is why for each of these four variables two indicators are constructed - the first indicator is equal to one if the given proportion is higher or equal to 0.34 and lower or equal to 0.66 , zero otherwise; and the second is equal to one if the given proportion is greater than 0.66 , zero otherwise. Such construction of the specific explanatory variables enables easy interpretation - the estimated parameters will be interpreted as difference from the reference category, i.e. the proportion is smaller than 0.34 . Altogether there are eight variables and their definitions are given in Table 1.

Though the samples differ for each modelling strategy, the proportions of female owners and directors are relatively stable. On average, $28 \%$ of owners and $26 \%$ of directors are females. Hence, the females are under-represented if we take into account that in 2011 the proportion of females in the age between 20 to 64 years was about $50 \% .{ }^{4}$ About $63 \%$ of the companies have proportion of females less than 0.33 , about $18 \%$ of the companies have relatively balanced ownership structure in terms of gender and about $19 \%$ of the companies have predominantly female owners. The situation with directors is very similar - about $66 \%$ of the companies have mostly male directors, about $16 \%$ of the companies have balanced composition of directors and about $18 \%$ are mostly females.

Regarding the proportion of education, there were about $45 \%$ owners and directors with university degree. Since, on average, there are about $19 \%$ of people between 20 to 64 years of age with university education, this group is clearly over-represented. If we look at the distribution of proportions, there are about $50 \%$ companies with owners or company directors nearly without a university degree, about $10 \%$ of the companies have balanced boards and $40 \%$ have boards with majority of people with university education.

Given the limitations of our sample (we knew the details about the people associated with the companies as of March 2013), the variables about the owners and company directors are constructed as time-invariant and we use them in models for each year in the estimation sample, i.e. 2012, 2013 and 2014. However, as the great majority of the companies are micro-entities with owners and company directors being the actual founders of the companies, we assume their turnover rate to be negligible and thus this limitation does not affect the obtained results (this issue is addressed later in the sensitivity analysis, and one of the sensitivity checks is estimation of cross-sectional models).

$4 \quad$ Statistical Office of the Slovak Republic, data from Census 2011. 


\section{ESTIMATION RESULTS}

For each dimension we report three model specifications - the first one includes only the control variables, the second one adds the explanatory variables related to gender composition and educational attainment of owners besides control explanatory variables, and the third one includes control variables and the variables related to company directors. The reason for the separate reporting is a high correlation between the gender characteristics of the company owners and directors, and also between the educational characteristics of the company owners and directors. ${ }^{5,6}$ One of the solutions of this problem is using the correlated variables separately and this is the approach we chose for this paper.

In order to check the stability of the results, three sensitivity checks are performed. Firstly, to control for the possible industry effect, we estimate the models separately for clusters of industry sectors based on the proportions of female owners and company directors. We rank the industry sectors based on the proportion of females in the company ownership structure and form four clusters of industry. ${ }^{7}$ The industry sectors in the same cluster are homogeneous in terms of gender composition and at the same time the clusters have approximately similar number of company-year observations. The second sensitivity check lies also in the estimation of the models for separate clusters but this time the industry sectors are clustered on the basis of the educational attainment. Thirdly, we rerun the models using the biggest possible common sample. This allows us to estimate the production function and default models for cross-sections, as well, which may provide further assurance of robustness of the results. ${ }^{8}$

\subsection{Efficiency/ Production function approach}

The results of the estimations are displayed in Table 2. The first model in Table 2 contains only the control explanatory variables and is included in the table for the sake of comparison and to confirm that the Cobb-Douglas specification generates

5 This correlation is caused by the fact that majority of these companies are small and the owners and directors are the same people.

6 The high correlation between explanatory variables is known as multicollinearity issue and its consequences include inflating of standard errors of the correlated variables, unstable coefficients' estimates and inability to discriminate the effects of the correlated variables on dependent variable.

7 As it turned out, the clustering based on proportions of females among company directors would yield exactly the same results.

8 Detailed results are available from the authors upon request. 
Table 2. Production function models

\begin{tabular}{|c|c|c|c|}
\hline Dependent variable & $\begin{array}{c}(1) \\
\text { Real value added } \\
(\log )\end{array}$ & $\begin{array}{c}(2) \\
\text { Real value added } \\
(\log )\end{array}$ & $\begin{array}{c}(3) \\
\text { Real value added } \\
(\log )\end{array}$ \\
\hline Labour (number of employees, log) & $\begin{array}{c}0.599^{* * *} \\
(105.88)\end{array}$ & $\begin{array}{c}0.600^{* * *} \\
(106.41)\end{array}$ & $\begin{array}{c}0.600^{* * *} \\
(106.38)\end{array}$ \\
\hline Capital (real fixed assets, log) & $\begin{array}{c}0.235^{* * *} \\
(82.49)\end{array}$ & $\begin{array}{c}0.233^{* * *} \\
(81.83)\end{array}$ & $\begin{array}{c}0.233^{* * *} \\
(81.72)\end{array}$ \\
\hline Age (years) & $\begin{array}{l}0.0221^{* * *} \\
(25.93)\end{array}$ & $\begin{array}{l}0.0198^{* * *} \\
(23.09)\end{array}$ & $\begin{array}{l}0.0198^{* * *} \\
(23.07)\end{array}$ \\
\hline Female - owners $(0.34-0.66)$ & & $\begin{array}{l}0.0251^{* *} \\
(2.20)\end{array}$ & \\
\hline Female - owners (over 0.66) & & $\begin{array}{l}-0.0609^{* * *} \\
(-5.07)\end{array}$ & \\
\hline Female - directors $(0.34-0.66)$ & & & $\begin{array}{l}0.0391^{* * *} \\
(3.27)\end{array}$ \\
\hline Female - directors (over 0.66) & & & $\begin{array}{l}-0.0503^{* * *} \\
(-4.12)\end{array}$ \\
\hline Education - owners $(0.34-0.66)$ & & $\begin{array}{l}0.102^{\text {*** }} \\
(6.75)\end{array}$ & \\
\hline Education - owners (over 0.66) & & $\begin{array}{c}0.187^{* * *} \\
(18.40)\end{array}$ & \\
\hline Education - directors $(0.34-0.66)$ & & & $\begin{array}{l}0.117^{* * *} \\
(7.52)\end{array}$ \\
\hline Education - directors (over 0.66) & & & $\begin{array}{l}0.183^{* * *} \\
(18.07)\end{array}$ \\
\hline Constant & $\begin{array}{c}6.823^{* * *} \\
(144.37)\end{array}$ & $\begin{array}{c}6.788^{* * *} \\
(143.08)\end{array}$ & $\begin{array}{c}6.786^{* * *} \\
(142.94)\end{array}$ \\
\hline Industry fixed effects & Yes & Yes & Yes \\
\hline Regional fixed effects & Yes & Yes & Yes \\
\hline Time fixed effects & Yes & Yes & Yes \\
\hline Size indicators & Yes & Yes & Yes \\
\hline Observations & 137,655 & 137,655 & 137,655 \\
\hline Companies & 58,965 & 58,965 & 58,965 \\
\hline $\mathrm{R}^{2}$ & 0.503 & 0.506 & 0.506 \\
\hline Standard errors & Clustered & Clustered & Clustered \\
\hline
\end{tabular}

Notes: The table displays the estimated parameters of micro-production functions. The dependent variable is the logarithm of value added in constant prices. The description of variables is in Table 1. The parameters are estimated using OLS (ordinary least squares) method. $* * *, * *$ and $*$ indicate that the coefficients are significant at the $1 \%, 5 \%$ and $10 \%$ levels, respectively (two-tailed tests, t-statistics in parentheses, calculated using standard errors adjusted for clusters within companies). 
reliable total factor productivity residuals. The results show that the estimated coefficients for labour and capital have expected sign and are highly statistically significant. Moreover, they are within the expected interval. ${ }^{9}$ Age is another explanatory variable in the model. Its coefficient is positive and highly statistically significant, suggesting that older firms are more effective with average increase in productivity of about $2 \%$ with each additional year of age. The model explains slightly more than $50 \%$ of the variability of the output.

Model 2 contains indicators of proportions of females among the company owners and the proportion of owners with university education, and model 3 contains those indicators for company directors. Results of both the models are similar. Companies with owners (or directors) both male and female in approximately balanced proportion are on average more productive than those with predominantly male owners (or directors) and even more so with predominately female owners (or directors). All else equal, these companies are about $2.5 \%$ more productive than the companies owned by males and $4 \%$ more productive than those directed by males.

The results indicate that the higher the proportion of the owners with university education, the higher is the company productivity. The effect is rather strong - when compared to the companies owned mostly owners without university degree, if the ownership is approximately balanced in terms of university education, the companies are on average more productive by $10 \%$ (almost $12 \%$ for balanced group of directors) and the average difference in productivity is nearly $19 \%$ if a company is owned mainly by university graduates (about $18 \%$ for directors with university degree).

The robustness check shows that the argument in favour of gender diversity is driven by cluster two, which is formed by a single industry ( $\mathrm{G}$ - Wholesale and Retail Trade; Repair of Motor Vehicles and Motorcycles), while in the remaining sectors it is true that the companies owned or represented by females are on average less productive. So the results of gender effect are industry specific. The results obtained by using the single cross-sectional common sample are similar to the main results. In terms of the impact of educational attainment of owners and directors on productivity, the results from the main models are confirmed and all models support the notion that higher proportion of owners and/or directors with university education is associated with higher productivity.

9 The neoclassical theory of production function assumes that the marginal products of labour and capital are positive (hence the coefficients should be positive) and subject to the law of diminishing returns (hence the coefficients should be smaller than one). 


\subsection{Turnover growth}

The estimation results are displayed in Table 3. The first model in Table 3 contains only the control variables and is included in the table for the sake of comparison. The estimations produce the expected signs for the control variables. On average, the bigger, more leveraged and older companies grow less. On the one hand, the market concentration does not seem to impact the turnover growth in relevant manner. On the other hand, companies operating in several industrial sectors enjoy on average about two percentage points higher annual growth in turnover. However, the percentage of explained variability in turnover growth is rather low and amounts to less than three per cent.

The results from models 2 and 3 suggest that the presence of females among the company owners or directors is associated with smaller average growth in turnover. The companies with gender balanced ownership structure (or directorship) grow by about two (or 1.5) percentage points less. If the proportion of females among company owners (or directors) is higher than two thirds, the growth is smaller by about 2.5 percentage points (in both cases the comparison is with the companies owned or directed predominantly by males).

The results suggest positive impact of education on turnover growth. A balanced mix of owners leads to more than 2.3 percentage points higher growth in turnover compared to the companies owned by owners without university education (almost two percentage points higher for directors). If over two thirds of the owners or directors have university degree, the growth in turnover is nearly two percentage points higher when compared with the companies owned or directed mainly by the owners without university education.

Results of the main models are confirmed partially by sensitivity analysis. The finding that the companies with female participation in ownership and company representation are on average associated with smaller growth of turnover is generally supported. The summary results of the effect of university education reported in the main models seem to be driven by the first two clusters, where the estimated coefficients are relatively high and statistically significant. The effect of education seems to be stable for companies owned and directed by people with university education. On the contrary, the reported significant effect of education in case of mixed educational ownership and company representation is generally not supported.

\subsection{Growth in total assets}

The estimation results of the models explaining the growth in total assets are reported in Table 4. The first model in Table 4 contains only the control variables. 
Table 3. Growth models (turnover)

\begin{tabular}{|c|c|c|c|}
\hline Dependent variable & $\begin{array}{l}\text { (1) } \\
\text { Real turnover } \\
\text { growth }\end{array}$ & $\begin{array}{l}\text { (2) } \\
\text { Real turnover } \\
\text { growth }\end{array}$ & $\begin{array}{c}\text { (3) } \\
\text { Real turnover } \\
\text { growth }\end{array}$ \\
\hline Size (Total assets, log) & $\begin{array}{l}-0.0402^{* * *} \\
(-24.54)\end{array}$ & $\begin{array}{l}-0.0409^{* * *} \\
(-24.86)\end{array}$ & $\begin{array}{l}-0.0410^{* * *} \\
(-24.87)\end{array}$ \\
\hline Total debt/ Total assets (w) & $\begin{array}{l}-0.0122^{* * * *} \\
(-3.77)\end{array}$ & $\begin{array}{l}-0.0118^{* * * *} \\
(-3.64)\end{array}$ & $\begin{array}{l}-0.0118^{* * *} \\
(-3.63)\end{array}$ \\
\hline HHI (turnover) & $\begin{array}{l}-0.0000142 \\
(-0.44)\end{array}$ & $\begin{array}{l}-0.0000134 \\
(-0.43)\end{array}$ & $\begin{array}{l}-0.0000136 \\
(-0.42)\end{array}$ \\
\hline Diversification indicator & $\begin{array}{l}0.0220^{* * *} \\
(3.56)\end{array}$ & $\begin{array}{l}0.0221^{* * *} \\
(3.57)\end{array}$ & $\begin{array}{l}0.0222^{* * *} \\
(3.58)\end{array}$ \\
\hline Age (years) & $\begin{array}{l}-0.00923^{* * *} \\
(-23.44)\end{array}$ & $\begin{array}{l}-0.00944^{* * *} \\
(-23.79)\end{array}$ & $\begin{array}{l}-0.00947^{* * *} \\
(-23.87)\end{array}$ \\
\hline Female - owners $(0.34-0.66)$ & & $\begin{array}{l}-0.0219^{* * *} \\
(-4.23)\end{array}$ & \\
\hline Female - owners (over 0.66 ) & & $\begin{array}{l}-0.0265^{* * *} \\
(-4.87)\end{array}$ & \\
\hline Female - directors $(0.34-0.66)$ & & & $\begin{array}{l}-0.0148^{* * *} \\
(-2.74)\end{array}$ \\
\hline Female - directors (over 0.66 ) & & & $\begin{array}{l}-0.0256^{* * *} \\
(-4.67)\end{array}$ \\
\hline Education - owners $(0.34-0.66)$ & & $\begin{array}{l}0.0237^{* * *} \\
(3.46)\end{array}$ & \\
\hline Education - owners (over 0.66) & & $\begin{array}{l}0.0186^{* * *} \\
(4.00)\end{array}$ & \\
\hline Education - directors $(0.34-0.66)$ & & & $\begin{array}{l}0.0186^{* * *} \\
(2.60)\end{array}$ \\
\hline Education - directors (over 0.66) & & & $\begin{array}{l}0.0196^{* * *} \\
(4.24)\end{array}$ \\
\hline Constant & $\begin{array}{c}0.613^{* * *} \\
(24.34)\end{array}$ & $\begin{array}{l}0.619^{* * *} \\
(24.42)\end{array}$ & $\begin{array}{l}0.619^{* * * *} \\
(24.38)\end{array}$ \\
\hline Industry fixed effects & Yes & Yes & Yes \\
\hline Regional fixed effects & Yes & Yes & Yes \\
\hline Size indicators & Yes & Yes & Yes \\
\hline Observations/ companies & 74,773 & 74,773 & 74,773 \\
\hline $\mathrm{R}^{2}$ & 0.0282 & 0.0289 & 0.0288 \\
\hline Standard errors & Robust & Robust & Robust \\
\hline
\end{tabular}

Notes: The table displays the estimated parameters of growth (turnover) models. The dependent variable is the compound annual growth rate of real turnover over two years. The description of variables is in Table 1. The parameters are estimated using OLS (ordinary least squares) method. ***,** and * indicate that the coefficients are significant at the $1 \%, 5 \%$ and $10 \%$ levels, respectively (two-tailed tests, t-statistics in parentheses, calculated using robust standard errors). 
Table 4. Growth models (total assets)

\begin{tabular}{|c|c|c|c|}
\hline Dependent variable & $\begin{array}{l}\text { (1) } \\
\text { Real total assets } \\
\text { growth }\end{array}$ & $\begin{array}{c}(2) \\
\text { Real total assets } \\
\text { growth }\end{array}$ & $\begin{array}{l}\text { (3) } \\
\begin{array}{c}\text { Real total assets } \\
\text { growth }\end{array} \\
\end{array}$ \\
\hline Size (Total assets, log) & $\begin{array}{l}-0.0841^{\text {*** }} \\
(-66.75)\end{array}$ & $\begin{array}{l}-0.0850^{* * *} \\
(-67.16)\end{array}$ & $\begin{array}{l}-0.0851^{* * *} \\
(-67.16)\end{array}$ \\
\hline Total debt/ Total assets (w) & $\begin{array}{l}-0.00322 \\
(-1.14)\end{array}$ & $\begin{array}{l}-0.00308 \\
(-1.09)\end{array}$ & $\begin{array}{l}-0.00314 \\
(-1.11)\end{array}$ \\
\hline HHI (turnover) & $\begin{array}{l}-0.0000263^{* * *} \\
(-4.24)\end{array}$ & $\begin{array}{l}-0.0000249^{* * *} \\
(-3.21)\end{array}$ & $\begin{array}{l}-0.0000247^{* * *} \\
(-3.52)\end{array}$ \\
\hline Diversification indicator & $\begin{array}{l}0.0183^{* * *} \\
(3.74)\end{array}$ & $\begin{array}{l}0.0180^{* * * *} \\
(3.69)\end{array}$ & $\begin{array}{l}0.0182^{* * *} \\
(3.72)\end{array}$ \\
\hline Age (years) & $\begin{array}{l}-0.00823^{* * *} \\
(-26.97)\end{array}$ & $\begin{array}{l}-0.00834^{* * *} \\
(-27.12)\end{array}$ & $\begin{array}{l}-0.00837^{* * *} \\
(-27.26)\end{array}$ \\
\hline Female - owners $(0.34-0.66)$ & & $\begin{array}{l}-0.0256^{* * *} \\
(-6.17)\end{array}$ & \\
\hline Female - owners (over 0.66 ) & & $\begin{array}{l}-0.0437^{* * *} \\
(-10.11)\end{array}$ & \\
\hline Female - directors $(0.34-0.66)$ & & & $\begin{array}{l}-0.0260^{* * *} \\
(-6.02)\end{array}$ \\
\hline Female - directors (over 0.66 ) & & & $\begin{array}{l}-0.0447^{* * *} \\
(-10.15)\end{array}$ \\
\hline Education - owners $(0.34-0.66)$ & & $\begin{array}{l}0.00825 \\
(1.50)\end{array}$ & \\
\hline Education - owners (over 0.66) & & $\begin{array}{l}0.00907^{* *} \\
(2.50)\end{array}$ & \\
\hline Education - directors $(0.34-0.66)$ & & & $\begin{array}{l}0.00486 \\
(0.85)\end{array}$ \\
\hline Education - directors (over 0.66) & & & $\begin{array}{l}0.0101^{* * *} \\
(2.80)\end{array}$ \\
\hline Constant & $\begin{array}{l}1.161^{* * *} \\
(59.85)\end{array}$ & $\begin{array}{l}1.178^{* * *} \\
(60.25)\end{array}$ & $\begin{array}{l}1.179^{* * *} \\
(60.30)\end{array}$ \\
\hline Industry fixed effects & Yes & Yes & Yes \\
\hline Regional fixed effects & Yes & Yes & Yes \\
\hline Size indicators & Yes & Yes & Yes \\
\hline Observations/ companies & 74,773 & 74,773 & 74,773 \\
\hline $\mathrm{R}^{2}$ & 0.110 & 0.112 & 0.112 \\
\hline Standard errors & Robust & Robust & Robust \\
\hline
\end{tabular}

Notes: The table displays the estimated parameters of growth (total assets) models. The dependent variable is the compound annual growth rate of real total assets over two years. The description of variables is in Table 1 . The parameters are estimated using OLS (ordinary least squares) method. $* * *, * *$ and $*$ indicate that the coefficients are significant at the $1 \%, 5 \%$ and $10 \%$ levels, respectively (two-tailed tests, t-statistics in parentheses, calculated using robust standard errors). 
Most of them produce the expected signs. On average, the bigger and older companies grow less. Unlike the former models, growth in total assets does not seem to be influenced by leverage. Alternatively, the market concentration seems to have a statistically significant impact. The companies grow more in competitive environment and so do those operating in multiple industrial sectors. The proportion of explained variability in dependent variable is about $11 \%$ - it is still rather small but somewhat higher than in the turnover growth models.

The overall pattern of gender effect is very similar to the turnover growth. The companies with higher representation of females among the company owners (or directors) achieve lower growth in total assets. It is about 2.5 percentage points lower growth for balanced gender composition and 4.4 percentage points lower growth for companies with mostly female owners or directors. The university education seems to play less significant role. The proportion of owners (or directors) with university education has to exceed two thirds to have a statistically significant impact and the size of the effect is lower than one percentage point.

These results were confirmed by sensitivity analysis, as well. On average the growth of total assets decreases with increasing proportion of females both among the owners and directors. This result is supported consistently across all the specifications. The university education seems to play some roles particularly in the second cluster formed by a single industry ( $\mathrm{G}$ - Wholesale and Retail Trade; Repair of Motor Vehicles and Motorcycles), otherwise the pattern is more complex. We discuss it in section 6 in greater detail.

\subsection{Survival/Bankruptcy}

The estimation results for the default models are displayed in Table 5. The first model contains only the control explanatory variables. All of them are statistically significant with the expected signs. The discriminatory performance of the model is also very good - the area under ROC curve is 0.878 .

Similar to the previous models, models 2 and 3 include explanatory variables related to female representation among company owners and directors along with their educational attainment. On the one hand, the coefficients of the indicators of balanced gender composition both among owners and directors attract negative signs and seem to suggest that gender diversity is associated with somewhat lower probability of default. However, they are statistically insignificant at the usual significance level of five per cent. On the other hand, the companies owned and represented by mainly females seem to have higher propensity to fail, yet these results lack the statistical significance, as well. The effect of university education on default probability does not seem to provide compelling evidence, 
Table 5. Default models

\begin{tabular}{|c|c|c|c|}
\hline Dependent variable & $\begin{array}{c}(1) \\
\text { default } \\
\end{array}$ & $\begin{array}{c}(2) \\
\text { default } \\
\end{array}$ & $\begin{array}{c}\text { (3) } \\
\text { default } \\
\end{array}$ \\
\hline Cash/ Total Assets (w) & $\begin{array}{l}-1.273^{* * *} \\
(-3.06)\end{array}$ & $\begin{array}{l}-1.303^{* * *} \\
(-3.13)\end{array}$ & $\begin{array}{l}-1.289^{* * *} \\
(-3.10)\end{array}$ \\
\hline Trade Creditors/ Total Liabilities (w) & $\begin{array}{l}1.536^{* * *} \\
(9.63)\end{array}$ & $\begin{array}{l}1.530^{* * *} \\
(9.62)\end{array}$ & $\begin{array}{l}1.522^{* * *} \\
(9.57)\end{array}$ \\
\hline Pre-tax profit/ Total Assets (w) & $\begin{array}{l}-2.076^{* * *} \\
(-7.02)\end{array}$ & $\begin{array}{l}-2.074^{* * *} \\
(-7.01)\end{array}$ & $\begin{array}{l}-2.072^{* * *} \\
(-7.03)\end{array}$ \\
\hline Net Worth/ Total Assets (w) & $\begin{array}{l}-0.794^{* * *} \\
(-9.01)\end{array}$ & $\begin{array}{l}-0.794^{* * *} \\
(-8.98)\end{array}$ & $\begin{array}{l}-0.791^{* * *} \\
(-8.99)\end{array}$ \\
\hline Size (Total assets, log) & $\begin{array}{l}0.573^{* * *} \\
(8.80)\end{array}$ & $\begin{array}{l}0.567^{* * *} \\
(8.71)\end{array}$ & $\begin{array}{l}0.568^{* * *} \\
(8.71)\end{array}$ \\
\hline Age (years) & $\begin{array}{l}0.0289^{* * *} \\
(3.07)\end{array}$ & $\begin{array}{l}0.0266^{* * *} \\
(2.80)\end{array}$ & $\begin{array}{l}0.0273^{* * *} \\
(2.90)\end{array}$ \\
\hline Female - owners $(0.34-0.66)$ & & $\begin{array}{c}-0.137 \\
(-0.82)\end{array}$ & \\
\hline Female - owners (over 0.66 ) & & $\begin{array}{l}0.0337 \\
(0.20)\end{array}$ & \\
\hline Female - directors $(0.34-0.66)$ & & & $-0.375^{*}(-1.90)$ \\
\hline Female - directors (over 0.66) & & & $0.0163(0.09)$ \\
\hline Education - owners $(0.34-0.66)$ & & $-0.0859(-0.43)$ & \\
\hline Education - owners (over 0.66) & & $0.217^{*}(1.73)$ & \\
\hline Education - directors $(0.34-0.66)$ & & & $0.0618(0.30)$ \\
\hline Education - directors (over 0.66) & & & $0.130(1.03)$ \\
\hline Constant & $\begin{array}{l}-14.85^{* * *} \\
(-14.94)\end{array}$ & $\begin{array}{l}-14.82^{* * *} \\
(-14.87)\end{array}$ & $\begin{array}{l}-14.80^{* * *} \\
(-14.91)\end{array}$ \\
\hline Industry fixed effects & Yes & Yes & Yes \\
\hline Regional fixed effects & Yes & Yes & Yes \\
\hline Time fixed effects & Yes & Yes & Yes \\
\hline Size indicators & Yes & Yes & Yes \\
\hline Observations & 212,668 & 212,668 & 212,668 \\
\hline Companies & 96,680 & 96,680 & 96,680 \\
\hline Log-likelihood & $-2,039.9$ & $-2,037.2$ & $-2,037.2$ \\
\hline Defaulted & 334 & 334 & 334 \\
\hline Area under ROC curve & 0.878 & 0.879 & 0.879 \\
\hline Standard errors & Clustered & Clustered & Clustered \\
\hline
\end{tabular}

Notes: The table displays the estimated parameters of default models. The dependent variable is binary, equal to one if the company defaulted, zero otherwise. The description of variables is in Table 1 . The parameters are estimated using logistic regression. $* * *, * *, *$ indicate coefficients are significant at the $1 \%, 5 \%$ and $10 \%$ levels respectively (two-tailed tests, z-statistics in parentheses, calculated using standard errors adjusted for clusters within companies). 
either, since none of the estimated coefficients related to the variables representing the educational attainment are statistically significant.

Lower probability of default of gender balanced company directors is somewhat supported but industry driven (cluster comprised of a single industry $G$ - Wholesale and Retail Trade; Repair of Motor Vehicles and Motorcycles). Sensitivity analysis confirmed that neither the gender diversity nor university education of stakeholders impacts the default probability.

\section{SUMMARY AND DISCUSSION}

Our paper tested the impact of educational and gender diversity on the performance of private firms in the Slovak economy.

\subsection{Gender composition and firm performance}

As described in Section 4, females are under-represented among owners and directors in the LLCs. This fact may be explained by the findings of Gino et al. (2015), who suggest that women overall aspire for more life goals than men and a smaller proportion of their goals is related to achieving power at work. Compared to men, women view high-level positions as less desirable. Both genders expect similar levels of positive outcomes related to high positions, but women expect more of negative outcomes (e.g. conflict) compared to men. This finding could offer some explanations why women are less represented among directors and why this trend could possibly continue. Due to different perceptions of what could holding a high position imply for themselves, women tend to desire higher management positions less than men.

From the results of our study we learn that the efficiency/productivity models support the gender diversity hypothesis only for a single industry sector of wholesale and retail trade. The companies with balanced proportion of females in ownership structure or among the company directors have on average higher total factor productivity. This industry sector accounts for $26.73 \%$ of companyyear observations in our sample. Its divisions ${ }^{10}$ include Wholesale and retail trade and repair of motor vehicles and motorcycles, Wholesale trade and Retail trade. A more detailed analysis reveals that the results are driven entirely by the division of Retail trade. This division itself accounts for about $13 \%$ of our sample.

10 The term "division" is used in accordance with the NACE Rev. 2 terminology (EC 2008) and represents a group of economic activities represented by two-digit code. 
Retail involves direct interaction with the customer and our result provides evidence that male-female cooperation increases the added value to the businesses. Moreover, unlike the rest of the estimation sample, in retail the female dominated businesses are more efficient than male ones, although less than the gender diverse companies. Interestingly, the incidence of the gender diverse and female dominated companies is relatively similar to the rest of the sample. In the division of Wholesale trade, there is partial evidence in favour of higher efficiency of the gender diverse companies, but the female dominated companies predominantly seem to be less efficient than those dominated by males. We see the possible reason in the fact that the argument of direct contact with customers applies to Wholesale trade only partially.

In the remaining industry sectors' clusters, the higher proportions of females are either associated with lower productivity, or these companies are no different from those with the majority of male owners or directors. Similarly, the companies with gender balanced ownership or directorship structures are as efficient as those with the male dominated ones.

The growth models do not provide any support for the gender diversity hypothesis. The results either show that the proportion of females does not play any role at all, or has an adverse effect on growth. This result seems to be particularly strong and stable across all models and specifications in that the estimated coefficient is always negative and it is statistically significant most of the times. One possible explanation is offered by gender differences in decision making, perception held or certain characteristic of behaviour. A study by Eagly - Steffen (1986) suggests that women are less likely to engage in dominant or aggressive behaviour than men. Bowles et al. (2007) found that women do not initiate negotiations as much as men. Women are different in their approach to making business deals, they view the social costs and economic benefits of engaging in certain negotiating behaviours differently (Morris et al. 1999). Women are less likely to self-select into competitive environments compared to men and are also less competitive than men (Buser et al. 2014). These intrapersonal effects could explain why a higher proportion of women among companies' owners or directors is associated with smaller growth of a company.

We study dimensions of the companies' performance that have not been subject to much research; nevertheless, we can refer to somewhat similar studies. Adams - Ferreira (2009) in their study of listed US companies find that gender diversity has a positive impact on performance of the firms that otherwise have weak governance, however, it has negative impact on the companies with strong governance. A study by Matsa - Miller (2013) on the impact of introducing gender quotas in Norway connects higher proportion of women on boards with the short-term decrease in firm's profits. Similarly, in our case the higher pro- 
portion of women among owners and company directors leads to lower growth for firms.

The default probability models do not provide convincing arguments for gender diversity in general. The diversity in owners and directors within a company seems to be irrelevant to the probability of default. However, marginally lower probability of default of gender balanced company directors is observed only in a single industry sector of wholesale and retail trade. Again, after more detailed analysis we find that this result is driven by division of Retail trade where the cooperation between male and female directors seems to be associated with lower propensity to fail. Interestingly, this does not hold for gender diversity of owners. As far as owners are concerned, the gender composition does not play any role in this sector either. A possible reason that the interaction between the male-female directors is relevant in retail trade may lie in the fact that the customer base is also gender balanced (the proportion of females in population is about $50 \%$, as we mentioned earlier). Hence, the cooperation of male and female directors may be particularly helpful in assessing and predicting the tastes of the customers. A recent study by Sila et al. (2016) finds that gender diversity in the boardroom has no impact on risk taking or risk aversion of a company, although they measure risk differently. Academic literature reports gender differences in risk taking and claims that males are more risk tolerant than females. Byrnes et al. (1999) provide a meta-analysis of 150 studies on the topic. However, Alexy et al. (2016) and Baláž et al. (2013) using the methods of experimental economics conclude that there are no significant differences in the risk attitudes between genders among the Slovak university students. These findings indicate that gender based risk attitudes may not play any role in the companies' performance in Slovakia. Our results confirm this conjecture with the exception of the division of Retail trade that there seem to be no association whatsoever between the gender composition of owners and directors and business failure.

\subsection{Educational attainment and firm performance}

Our construction of explanatory variables allows us to test two conjectures. Firstly, drawing on the argument of diversity, the combination of owners and directors in terms of education may be beneficial to a company. This viewpoint implicitly assumes that university education brings a different perspective and at the same time the perspective and contribution of a person without university education is equally valuable. People with accumulated business experience (specific business knowledge) may indeed complement those with university education (general business knowledge) and create synergies. Secondly, if a person with uni- 
versity degree provides superior human and social capital to a company, then the companies with higher proportions (or majority) of owners and/or directors with tertiary education should perform better. This conjecture implicitly assumes that university education provides a unique resource in the form of human and social capital which cannot be provided without it. Also, to a certain extent, it is in line with the notion that education is a proxy for inner non-observable abilities.

In the previous section we documented rather a significant and stable finding that university education is associated with higher efficiency measured by production function. The relationship appears to be monotonic that is the companies with higher proportion of owners or directors with university degree are more efficient. This finding is in line with the theories of increased human and social capital. Greater skill set and wider network of contacts allow companies to achieve greater efficiency. Our results are supported by the similar findings for listed companies. According to Hitt et al. (2001), students from the top-ranking universities have opportunity to acquire the highest degree of codified knowledge, they have the potential to learn and accumulate tacit knowledge, and thus the company should benefit from them the most, particularly if the managers are well educated. Audretsch - Lehmann (2006) find that the directors with academic background can contribute to a company by facilitating access to external knowledge spillovers and their absorption in the company, since they are experts in their particular fields. King et al. (2016) go further and suggest that type of education matters, as well. They report that MBA education enables bank CEOs to achieve superior performance when compared to their peers. However, we are not able go that far because our data do not discriminate types of education.

In terms of growth, both turnover and growth in total assets are related to education of the company owners and directors. However, the sensitivity analysis revealed that the effect is stronger in the sectors with lower average proportions of owners and directors with university degree. It seems that the differences in growth diminish after certain threshold is achieved. Also, the impact of education on turnover growth is higher and statistically significant in more instances than in the case of growth in total assets. Since turnover is related to operating activity, this finding is in line with the argument that education contributes to greater efficiency but its impact is not significant on the long-term strategic decisions, such as growth of company in total assets. Another possible explanation is that there are no significant differences in ambitions and vision between the people with university education and those without.

The education of owners or company directors does not seem to influence the probability of default - neither in the case of diverse representation nor in the case of majority. This may be surprising, since it is assumed that university education should increase human capital in the form of specific and general skills 
and social capital in the form of social connections. If this is true, then once a company experiences a financial distress, superior knowledge and a wider network of social contacts should result in a broader set of options of how to deal with the upcoming crisis. However, various factors may also decrease a value of the potential human and social capital (e.g. a university graduate may take riskier projects as a consequence of excessive self-confidence, education can be of lower quality or the knowledge gained from education may become outdated).

Overall, our results provide evidence in favour of the argument that education is a unique resource (see discussion in the beginning of this sub-section). Barney (1991) and Galunic -Rjordan (1998) suggest that the diversity in company's workforce contributes to its business results; and the human capital diversity provides a source for competitive advantage as it combines specific expertise and social skills. This does not seem to be true in the case of diversity in education because throughout all the reported specifications the coefficients for the companies with balanced educational composition of owners and directors are rarely greater than those for the companies with majority of owners and directors with university degree. Perhaps the lower frequencies might influence these results as there are just about $10 \%$ of company-year observations with education diversified companies. However, the argument of uniqueness seems to be stronger than the argument of diversity and if we take into account all the specific results we may say that education is a unique resource and it benefits a company by having either an owner or a director with university degree.

\subsection{Limitations of the study}

Because of the data limitations, we focus on a relatively shorter period of time of three years (2012-2014), which is not a representative sample since it does not cover all phases of economic cycle. Secondly, we draw inferences from the characteristics of owners and executive directors whereas it would be helpful to take into account the gender and education profiles of all the employees, especially those from the senior management. Thirdly, our data do not allow us to control for the finer details related to education that would be beneficial for explaining firm's performance, such as field of study, university ranking or year of graduation. Fourthly, we use relatively simple model specifications but the reality may be more colourful and perhaps future studies may include various interactions recognizing the fact that the effects may differ for various groups and settings. 


\section{CONCLUSION}

The paper tests the impact of gender diversity and educational attainment of the company owners and directors on the performance of the private firms. A sample of the limited liability companies from the Slovakian economy covering the period of 2012-2014 is utilised. The performance is approached from several aspects: the efficiency is assessed using the production function approach, growth is explored along two dimensions of turnover and total assets and finally the impacts of gender and education diversity on the companies' survival are evaluated.

The gender diversity both among owners and directors within a company leads to higher efficiency in retail trade. The companies with gender diverse directors have also lower propensity to fail. We explain the possible reasons with the fact that the retail division involves direct interaction with the customers and our result provides evidence that male-female cooperation increases the added value to the businesses. In other industries, the companies with higher proportion of females in ownership structure or among company directors tend to grow less and are less efficient, and this result was confirmed both along the turnover and total assets dimensions. We suggest the relevance of these results when tailoring the economic policy, e.g. imposing gender quotas.

In terms of educational attainment, the companies with higher proportions of owners or directors with university education are more efficient when compared to the companies led or owned by people without any university degree. Similarly, these companies seem to grow relatively more in terms of turnover and partially in terms of total assets. Interestingly, when controlled for other relevant determinants, education does not seem to impact business failure. However, our results provide evidence that education is a unique and superior resource and owners and company directors are to be encouraged to increase their human capital by gaining university education.

\section{REFERENCES}

Adams, R. B. - Ferreira, D. (2009): Female in the Boardroom and Their Impact on Governance. Journal of Financial Economics, 94(2): 291-309.

Alexy, M. - Georgantzis, N. - Káčer, M. - Péliová, J. (2016): Risk Attitude Elicitation Methods: Do They Tell Similar Stories? Journal of Economics (Ekonomický časopis), 64(9): 847-877.

Altman, E. I. (1968): Financial Ratios, Discriminant Analysis and the Prediction of Corporate Bankruptcy. The Journal of Finance, 23(4): 589-609.

Altman, E. I. - Sabato, G. - Wilson, N. (2010): The Value of Non-Financial Information in Small and Medium-Sized Enterprise Risk Management. Journal of Credit Risk, 6(2): 95-127.

Anderson, R. - Reeb, D. - Upadhyay, A. - Zhao, W. (2011): The Economics of Director Heterogeneity. Financial Management, 40(1): 5-38. 
Audretsch, D. B. - Lehmann, E. (2006): Entrepreneurial Access and Absorption of Knowledge Spillovers: Strategic Board and Managerial Composition for Competitive Advantage. Journal of Small Business Management, 44(2): 155-166

Baláž, V. - Bačová, V. - Drobná, E. - Dudeková, K. - Adamík, K. (2013): Testing Prospect Theory Parameters. Journal of Economics (Ekonomický časopis), 61(7): 655-671.

Barney, J. B. (1991): Firm Resources and Sustained Competitive Advantage. Journal of Management, 17(1): 99-120.

Barney, J. B. (2001): Is the Resource-Based "View" a Useful Perspective for Strategic Management Research? Yes. Academy of Management Review, 26(1): 41-56.

Bartoš, P. - Rahman, A. - Horák, J. - Jáčová, H. (2015): Education and Entrepreneurship in the SME Segment in Economic Transformation. Economics \& Sociology, 8(2): 227-239.

Beaver, W. H. (1966): Financial Ratios as Predictors of Failure. Journal of Accounting Research, 4: 71-111.

Bowles, H. R. - Babcock, L. - Lai, L. (2007): Social Incentives for Gender Differences in the Propensity to Initiate Negotiation: Sometimes It Does Hurt to Ask. Organizational Behavior And Human Decision Processes, 103(1): 84-103.

Brammer, S. - Millington, A. - Pavelin, S. (2007): Gender and Ethnic Diversity among UK Corporate Boards. Corporate Governance, an International Review, 15(2): 393-403.

Brunninge, O. - Nordqvist, M. - Wiklund, J. (2007): Corporate Governance and Strategic Change in HSMEs: The Effects of Ownership, Board composition and Top Management Teams. Small Business Economics, 29(3): 295-308.

Buser, T. - Niderle, M. - Oosterbeek, H. (2014): Gender, Competitiveness, and Career Choices. The Quarterly Journal of Economics, 129(3): 1409-1447.

Bútorová, Z. - Bosá, M - Filadelfiová, J. - Gyárfášová, O. - Minarovič, M. - Sekulová, M. Šumšalová, S. - Velšic, M. (2008): She and He in Slovakia. Gender and Age in the Period of Transition. Institute for Public Affairs, Bratislava.

Byrnes, J. P. - Miller, D. C. - Schafer, W. D. (1999): Gender Differences in Risk Taking: A MetaAnalysis. Psychological Bulletin, 125(3): 367-383.

Carter, D. A. - D’Souza, F. - Simkins, B. J. - Simpson, W. G. (2010): The Gender and Ethnic Diversity of US Boards and Board Committees and Firm Financial Performance. Corporate Governance: An International Review, 18(5): 396-414.

Eagly, A. H. - Steffen, V. J. (1986): Gender and Aggressive Behavior: A Meta-Analytic Review of the Social Psychological Literature. Psychological Bulletin, 100(3): 309-330.

Erhardt, N. L. - Werbel, J. D. - Shrader, C. B. (2003): Board of Director Diversity and Firm Financial Performance. Corporate Governance: An International Review, 11(2): 102-111.

Eriksson, T. (2005): Managerial Pay and Executive Turnover in the Czech and Slovak Republics. Economics of Transition, 13(4): 659-677.

European Communities (2008): NACE Rev. 2, Statistical Classification of Economic Activities in the European Community. Luxembourg: Office for Official Publications of the European Communities. http://ec.europa.eu/eurostat/documents/3859598/5902521/KS-RA-07-015-EN.PDF

Fidrmuc, J. - Senaj, M. (2014): Income, Schooling and Housing Wealth during Economic Reforms. Czech Journal of Economics and Finance (Finance a úvěr), 64(2): 160-176.

Galunic, D. C. - Rjordan, S. (1998): Resource Recombinations in the Firm: Knowledge Structures and the Potential for Schumpeterian Innovation. Strategic Management Journal, 19(12): 1193-1201.

Gino, F. - Wilmuth, C. A. - Brooks, A. V. (2015): Compared to Men, Women View Professional Advancement as Equally Attainable, but Less Desirable. Proceedings of the National Academy of Sciences of the United States of America, 112(40): 12354-12359. 
Hitt, M. A. - Bierman, L. - Shimizu, K. - Kochhar, R. (2001): Direct and Moderating Effects of Human Capital on Strategy and Performance in Professional Service Firms: A Resource-Based Perspective. Academy of Management Journal, 44(1): 13-28.

Huse, M. - Nielsen, S. - Hagen, I. (2010): Boards of Directors, Codetermination and Women Directors: Societal and Business Case CSR Illustrations from Norway. Journal of Business Ethics, 89(4): 581-597.

Jehn, K. A. - Northcraft, G. B. - Neale, M. A. (1999): Why Differences Make a Difference: A Field Study of Diversity, Conflict, and Performance in Workgroups. Administrative Science Quarterly, 44(4): 741-763.

Kang, H. - Cheng, M. - Gray, S. J. (2007): Corporate Governance and Board Composition: Diversity and Independence of Australian Boards. Corporate Governance: An International Review, 15(2):194-207.

King, T. - Srivastav, A. - Williams, J. (2016): What's in an Education? Implications of CEO Education for Bank Performance. Journal of Corporate Finance, 37: 287-308.

Matsa, D. A. - Miller, A. R. (2013): A Female Style in Corporate Leadership? Evidence from Quotas. American Economic Journal Applied Economics, 5(3): 136-169.

Morris, M. W. - Larrick, R. P. - Su, S. K. (1999): Misperceiving Negotiation Counterparts: When Situationally Determined Bargaining Behaviors are Attributed to Personality Traits. Journal of Personality and Social Psychology, 77(1): 52-67.

Ohlson, J. A. (1980): Financial Ratios and the Probabilistic Prediction of Bankruptcy. Journal of Accounting Research, 18(1): 109-131.

Shumway, T. (2001): Forecasting Bankruptcy More Accurately: A Simple Hazard Model. The Journal of Business, 7(1): 101-124.

Sila, V. - Gonzalez, A. - Hagendorff, J. (2016): Women on Board: Does Boardroom Gender Diversity Affect Firm Risk? Journal of Corporate Finance, 36: 26-53.

van der Zwan, P. - Thurik, R. - Verheul, I. - Hessel, J. (2016): Factors Influencing the Entrepreneurial Engagement of Opportunity and Necessity Entrepreneurs. Eurasian Business Review, 6(3): 273.

van Praag, M. - van Witteloostuijn, A. - van der Sluis, J. (2009): Returns for Entrepreneurs vs. Employees: The Effect of Education and Personal Control on the Relative Performance of Entrepreneurs vs. Wage Employees. IZA Discussion Paper Series, No. 4628, Institute for the Study of Labor.

Wilson, N. - Altanlar, A. (2014): Company Failure Prediction with Limited Information: Newly Incorporated Companies. Journal of the Operational Research Society, 65(2): 252-264.

Wilson, N. - Ochotnický, P. - Káčer, M. (2016): Creation and Destruction in Transition Economies: The SME Sector in Slovakia. International Small Business Journal, 34(5): 579-600.

Wilson, N. - Wright, M. - Scholes, L. (2013): Family Business Survival and the Role of Boards. Entrepreneurship Theory and Practice, 37(6): 1369-1389.

Zmijewski, M. E. (1984): Methodological Issues Related to the Estimation of Financial Distress

Prediction Models. Journal of Accounting Research, 22(2): 59-82. 